\title{
O OBRAZOWANIU IDEI SPRAWIEDLIWOŚCI W RZECZYPOSPOLITEJ POŁOWY XVIII WIEKU - WOKÓŁ KONFLIKTU O ORDYNACJĘ OSTROGSKĄ
}

W latach pięćdziesiątych XVIII wieku Rzecząpospolitą wstrząsnęła sprawa ordynacji ostrogskiej. Utworzona przez księcia Janusza Ostrogskiego w 1609 r., złożona z 21 miast i blisko 600 wsi, była największą ordynacją w Koronie. Na początku lat 50. znajdowała się we władaniu marszałka nadwornego litewskiego Janusza Sanguszki, który z powodu długów rozdzielił ją (bez zgody sejmu) między 34 wierzycieli, na mocy układu zawartego w Kolbuszowej 7 grudnia 1753 r. Największymi beneficjentami podziału stali się Lubomirscy, natomiast główny ciężar odporu ataków przeciwników wziął na siebie wojewoda ruski August Aleksander Czartoryski. Do transakcji kolbuszowskiej wrogo była nastawiona większość szlachty, uznając, że jest to pogwałcenie praw obowiązujących w Rzeczypospolitej. Głównym przeciwnikiem podziału okazał się hetman wielki koronny Jan Klemens Branicki. Z jego inicjatywy 18 stycznia 1754 r. we Lwowie został wniesiony manifest potępiający transakcję kolbuszowską. Ludzie hetmana już w lutym 1754 r. zajęli Dubno (główną siedzibę Janusza Sanguszki). Tłumaczono to względami bezpieczeństwa, gdyż ordynacja miała obowiązek wystawić 600 żołnierzy do obrony granic Rzeczypospolitej, czego po podziale nie czyniła. August III reskryptem z 2 września 1755 r. przekreślił układ kolbuszowski i powołał komisję mającą zlustrować dobra, zwaną komisją dubieńską. 10 maja 1758 r. mocą reskryptu królewskiego dobra powróciły do Janusza Sanguszki, bez możliwości ich zbycia. W 1766 r. sejm uznał je za zwyczajne dobra ziemskie,

Dr hab. Krzysztof Gombin - Katolicki Uniwersytet Lubelski Jana Pawła II, Wydział Nauk Humanistycznych, Instytut Nauk o Sztuce, Katedra Historii Sztuki Średniowiecznej i Nowożytnej; adres do korespondencji: Al. Racławickie 14, 20-950 Lublin; e-mail: krzysztof.gombin@ kul.pl; ORCID: https://orcid.org/0000-0002-0097-2518. 
czyli podlegające parcelacji ${ }^{1}$. Transakcja kolbuszowska dawała możliwości zysków jej uczestnikom, ale mogła też być zaczątkiem nowego stronnictwa skupionego wokół „Familii” (Szwaciński 37).

Niniejszy artykuł ma za zadanie ukazanie roli i wzajemnych relacji sztuk plastycznych, ceremoniału oraz publicystyki w propagandzie politycznej Rzeczypospolitej czasów panowania Augusta III na jednym, ale za to kluczowym dla ówczesnego życia publicznego przykładzie. Spór o ordynację ostrogską tak bardzo bowiem rozniecał emocje współczesnych, że znalazł odzwierciedlenie zarówno w grafice, literaturze satyrycznej, jak i ceremoniale królewskiej komisji. Tylko na podstawie analizy porównawczej wszystkich wymienionych elementów można odtworzyć obraz ówczesnych działań propagandowych.

W relacjach przeciwników podziału ordynacji był on przedstawiany jako przejaw całkowitego bezprawia, a wszelkie działania przeciw niemu - jako próba przywrócenia ładu w Rzeczpospolitej. Spór o ordynację znalazł oddźwięk w dwóch utworach satyrycznych, znanej z kilkunastu rękopiśmiennych odpisów Łysej radzie kolbuszowskiej oraz Scenie tragiczno-komicznej publicznym światu polskiego theatrum pokazanej wyrok niewinnej śmierci i cudownego po tym uwolnienie ordynacyi ostrogskiej prezentujacej Ojczysta Muza przez jednego ze spektatorów opisanej ${ }^{2}$, a także w dużej liczbie prawniczych rozprawek, w większości pozostających do dzisiaj w rękopisach ${ }^{3}$.

Przeciwnicy podziału ordynacji, skupieni wokół hetmana wielkiego koronnego Jana Klemensa Branickiego, starali się w przekazie publicznym ukazać ten fakt jako akt całkowitego bezprawia. W satyrycznej Scenie tragiczno-komicznej zawarcie transakcji kolbuszowskiej zostało przedstawione jako parodia sądów działających w Rzeczypospolitej:

Dylekt serdeczny i sekretny pono

Marszałka Litwy Sanguszka Książęcia

Dał mu do tego radę przedsięwzięcia

${ }^{1} \mathrm{Z}$ syntetycznych prac dotyczących dziejów konfliktu o ordynację wciąż aktualne pozostają teksty Władysława Konopczyńskiego, zwłaszcza „Ostrogska ordynacja” 793-797 i Polska w dobie wojny siedmioletniej cz. 1 passim; zob. też: Gombin, „O reminiscencjach konfliktu” 191-203.

${ }^{2}$ Por. Buchwald-Pelcowa, Satyra czasów saskich 192-193, 265. Tam też sygnatury najważniejszych odpisów.

${ }^{3}$ Por. na przykład Archiwum Główne Akt Dawnych (AGAD), Zbiór Anny z Potockich Ksawerowej Branickiej, sygn. 1813. Ordynacja ostrogska. Prawdzic do niewiadomego; tamże, sygn. 469. Rękopisy dotyczace ordynacji ostrogskiej; Zbiór Branickich z Suchej, sygn. 131. Manuscripta anni 1754; Akta publiczne do interessu ordynacji ostrogskiej nalezaçe [b.d.m.w.], ok. 1754. 
Aby po dóbr swych dziedzicznych żałobie,

Y Ordynackie pozwolone sobie

Tylko do czasu za własne swe niby

Rozdział podziałem y już bez ochyby

Tak być ma już się pretendenci zbiegli

Dwór Kolbuszowski i miasto oblegli

Radzą przy winie jak ordynacyą

Obwinić więc tę wnoszą illacyą

Ze nazbyt skapa, bo tylko jednego

Żywi za to iuż idzie przed sędziego

Sądzi Koronny Kanclerz Aktor Książę

Marszałek z świadkiem Szydłowskim przysiąże

Instygatorem y mówcą wraz Dłuski

Obrońca Sądu Wojewoda Ruski

A Lubomirscy jak żołnierze stoją

Czekając rychło im dadzą w moc swoją.

$\mathrm{W}$ to się tę niewinną chcąć jako najprędzej

Porwać ją, aż gdy podsypią pieniędzy

Wypada z Sądu Sentencja zgodna

Że ćwiartowania na sztuki jest godna.

Tak utwierdzeni bezprawnym wyrokiem

Pogląda każdy na niewinność okiem

Skąd jej szarpnąć jak uchwycić lepij

Apetyt wszystkich ledwo nie oślepi ${ }^{4}$.

Warto przyjrzeć się bliżej temu fragmentowi. Zgodnie z jego przekazem, nie tylko bowiem wyrok woła w tym przypadku o pomstę do nieba, ale również wszystkie elementy „sądowego” postępowania. Uczestnicy procesu „Radzą

\footnotetext{
${ }^{4}$ Biblioteka Jagiellońska, rkps 1808 IV. Scena tragiczno-komiczna publicznym światu polskiego theatrum pokazana wyrok niewinnej śmierci i cudownego po tym uwolnienie ordynacyi ostrogskiej prezentujaca Ojczysta Muza przez jednego ze spektatorów opisana. Warto zwrócić uwagę na pewną zbieżność, zapewne nieprzypadkową, dotyczącą słownictwa użytego w tytule dramatu $\mathrm{z}$ fragmentem kazania wygłoszonego podczas wotywy rozpoczynającej sejm $1754 \mathrm{r}$., mający zająć się sprawą podziału ordynacji ostrogskiej. Ksiądz Maciej Łubieński mówił: „Ale gdzież proszę jest najwięcej niezgody, jako u nas Polaków? Gdzie by się jej z wyrażonych tu teraz przyczyn spodziewać najmniej potrzeba, albowiem mijam inne nieubłaganych zawziętości i zawistności Teatra, nie wspominam onychże tragiczne Sceny, do samych tylko zjazdów publicznych idę; Jak wiele na tychże szabla Polska niegdyś nieprzyjaciołom wiary S. y Ojczyzny naszej straszliwa, teraz na Synów onejże a swoich Współbraci okrutna (...)" (Kazanie na seymie ordynatyinym warszawskim Roku Pańskiego 1754 przez Macieja Józefa z Łubny Lubieńskiego Archidiakona Katedralnego Krakowskiego, proboszcza Kollegiaty S. Michała na Zamku w Krakowie miane Y do druku za pozwoleniem Starszych Roku tegoż podane. A po tym dla niedostatku Exemplarzow z poprawa errorów druku, ktoe się $w$ tamtych znaydowaty, $w$ Roku nastęuiacym przedrukowane, w Krakowie w Drukarni J.O Jego MCI Biskupa Krakowskiego D2v).
} 
przy winie jak ordynacją obwinić". Pijaństwo sędziów, podejmowanie decyzji nie za sądowym stołem, ale podczas uczt, nierzadko w gospodach, to jeden z najczęściej krytykowanych aspektów staropolskiego sądownictwa. W tym przypadku zresztą miejscem akcji jest „dwór kolbuszowski”, a więc miejsce do tego ze wszech miar niewłaściwe. Wszyscy uczestniczący w tej parodii sądu reprezentują oczywiście jedną stronę, a ich główną motywacją jest chęć zysku („gdy podsypią pieniędzy wypada z sądu sentencja zgodna”), co do znudzenia wręcz krytykowano w ówczesnej publicystyce (Gombin, Trybunat Koronny 173 n.).

Prezentowany powyżej opis bezprawia i rozkładu Rzeczypospolitej ma swoisty odpowiednik w rycinach ilustrujących rozprawę Piotra Hadziewicza Prawda obiaśniona, pozory przyćmione, ordinacyia obroniona to iest odpowiedź na ksiaszkę (sic!) Uwagi w sprawie ordynacyi ostrogskiey oraz Wolność oswobodzona z niewoli swawolney ubezpieczone prawa y seymy oswobodzona oyczyzna (Wrocław, 1756). W tym wszakże przypadku mamy do czynienia z wzorami pozytywnymi. Dzieło Hadziewicza było odpowiedzią na wydaną anonimowo, w 1754 r., przez związanego z Czartoryskimi Tomasza Dłuskiego, broniącą podziału ordynacji rozprawkę zatytułowaną Uwagi w sprawie ordynacji ostrogskiej. Ilustracje do Prawdy obiaśnionej wykonał we Wrocławiu Bartłomiej Strachowski ${ }^{6}$. Miedzioryt na stronie tytułowej (il. 1) został u dołu opatrzony inskrypcją wpisaną w rokokowy kartusz: „Justitia regna florebunt". Jedynie przestrzeganie obowiązującego prawa stanowi gwarancję rozwoju Rzeczypospolitej. Na ilustracji został przedstawiony orzeł z piorunami w szponach oraz taśmą z napisem: „Virtuti praemuim, crimini Supplicium". Poniżej, po lewej stronie kompozycji, pod baldachimem, stoi personifikacja Polski, w wieńcu laurowym, z której ust biegnie inskrypcja przestrzegająca przed konsekwencjami bezprawia: „Lex nulla, torva lis, furens discordia”. Kobieta prawą ręką dotyka królewskich insygniów znajdujących się na wezgłowiu ułożonym na rockaillowej „strukturze fantastycznej" "7. Lewą ręką wskazuje na symboliczny sąd dokonany nad podziałem ordynacji ostrogskiej. Wyłaniająca się z chmur Manus Dei waży na szalach wagi $\mathrm{z}$ prawej strony akty prawne będące podstawą dotychczasowego funkcjonowania ordynacji („Ius vetandi przy prawie 1673. fol. 2 tit [ulus] Constitutio pacificationis; 1690 fol. 1 tit[ulus] Obiaśnienie

\footnotetext{
${ }^{5}$ Por. Górska, Polonia. Tam też podstawowa literatura przedmiotu.

${ }^{6}$ Por. Więcek, Strachowscy passim. Dwa z miedziorytów z Prawdy obiaśnionej są sygnowane. Miedzioryt na stronie tytułowej: „Strachowsky del. et sculpsit Vratislaviae” oraz s. 2: „Strachowsky delin. et sculps. Vratislaviae”.

${ }^{7}$ Tego nadzwyczaj trafnego określenia używam za Magdaleną Witwińską (53 n.).
} 
poobraniu dnia pierwszego Marszałka”), z drugiej zaś odnoszącą się do umowy kolbuszowskiej kartę z tekstem: „Arbitriapro legibq. Privata commoda” z inskrypcją: „Pulvis et Umbra summus”. Prawa szala okazuje się zdecydowanie cięższa. Tak więc panujący dotychczas w Rzeczypospolitej ład zwycięża. Pod wagą został wyobrażony pęknięty glob z podzieloną Małopolską, Wołyniem, Ukrainą i Prusami. Wypada zgodzić się z Magdaleną Górską, że symbolizujący tu virtus wieniec laurowy „na głowie personifikacji przedstawiał ją jako wcielenie wspólnoty obywatelskiej" (Górska 252). Orzeł (heraldyczny) z piorunami stanowi nawiązanie do Gigantomachii, motywu bardzo często wykorzystywanego w XVII-wiecznej Rzeczypospolitej w graficznych przedstawieniach propagandowych ${ }^{8}$. Jowisz karze w tym przypadku tych, którzy doprowadzili do rozłamu w państwie, a więc ów pęknięty glob to nie tylko, jak sugeruje Górska (252), zapowiedź upadku Rzeczypospolitej, ale także ukazanie istniejącego już jej rozłamu, który należy, posiłkując się obowiązującym ładem prawnym, zlikwidować.

Gwarantem pochodzącego od Boga porządku prawnego jest król, on współdziała z pozostałymi stanami sejmującymi ${ }^{9}$. Na kolejnej rycinie ilustrującej traktat Hadziewicza (il. 2) Fama, zgodnie z zawieszoną na trąbie inskrypcją, sławi monarchę: „Vivat Augustus Rex et Protector”. Na tle wschodzącego słońca, mającego zastąpić kończącą się właśnie noc, symbolizowaną przez gwieździste niebo, w ogrodowych szpalerach stoją personifikacje Sprawie-

\footnotetext{
${ }^{8}$ Por. Chrościcki, „Gigantomachia, komety i ulotki” $121 \mathrm{n}$. Warto dodać, że bardzo podobny wątek był obecny na inskrypcji imieninowych (drugiego imienia) cukrów Jana Klemensa Branickiego, urządzonych 19 listopada 1756 r. w Piotrkowie przez stolnika radomskiego Józefa Jankowskiego:

„Jako świat Polski widzi Klemensa męstwo,

Tak przyczyna razem z ludzkich serc Jego zwycięstwo.

Niech przy Jowiszu Orzeł grzmot, pioruny głosi,

Nam łaski od Gryff Branickich od Tronu przynosi” (Kuryer Polski, 1756, nr 176). Opisu samych cukrów nie znamy.

${ }^{9} \mathrm{~W}$ sposób niezwykle trafny ujął to w kazaniu na rozpoczęcie sejmu 1754 r., mającego zajmować się sprawą ostrogską, cytowany już, Maciej Łubieński: „U nas chcę mówić jeszcze w tej tu Rzeczypospolitej naszej która coś więcej nad inne podobieństwa wyraża na sobie do stworzonego od Boga człowieka jakom teraz nadmienił, tak z należytą od Przodków naszych symetrią uformowana. Ma albowiem za Duszę swoją, która całe jej polityczne corpus ożywia, wolność przy prawach. Trzy tę duszę sprawują potencje, to jest trzy stany które nami rządzą. Ma to samo polityczne naszej Rzeplitej corpus za głowę N. P. Za serce największą mające z głową komunikacją Prześwietny Senat; za ręce do obrony, y piersi do zastawiania waleczne Rycerstwo. Na ostatek jako każdego człowieka w rozumieniu moralnym część wyższa co do Ducha, część niższa co do ciała zowie się, tak Rzplita Nasza, y ten skład doskonały, z dwojakiego powołaniu swoim różniącego się stanu, Duchownego to jest Świeckiego w sobie jednej zamyka" (Łubieński Cv).
} 
dliwości (kobieta z zawiązanymi oczami, trzymająca w jednej ręce miecz, a w drugiej wagę) oraz Opatrzności trzymającej w dłoni kartę z inskrypcją: „1618. Ordinacija Ostrogska”. Obie postacie są zwrócone ku ogrodowej fontannie, na której zostały umieszczone daty odnoszące się do kolejnych związanych z funkcjonowaniem ordynacji ostrogskiej uregulowań prawnych: „1609, 1624, 1627, 1628, 1635, 1667, 1673, 1677, 1645, 1664”. Kąpiące się w fontannie putto trzyma inskrypcję: „1609 fol. 895 tit. Ordinatio”, a na basenie czytamy: „prawa i dekreta seymowe Ordinacij służące”. Tak więc przy przestrzeganiu prawa zło symbolizowane przez ciemność minie „Discutit Umbras” - jak głosi odnosząca się do ilustracji inskrypcja.

Uzupełnieniem komentarza do sytuacji bieżącej jest także inicjał (litera D) $\mathrm{w}$ formie drzewa $\mathrm{z}$ pajęczyną (il. 3), nawiązujące do poglądów przypisywanych Solonowi: „Prawa są podobne do pajęczyny: jeżeli dostanie się do niej stworzenie małe i słabe, nie może się wydostać, ale stworzenie większe rozerwie ją i spokojnie poleci dalej” (Górska 253) ${ }^{10}$. Rozprawę Hadziewicza kończy symboliczne przedstawienie zaćmienia księżyca (il. 4), rzucającego cień na herb Ostrogskich ${ }^{11}$. Przy tym należy dodać fakt, dość oczywisty, ale w tym miejscu konieczny, że rzadkie zjawiska astronomiczne, takie jak między innymi zaćmienia, były postrzegane jako wyjątkowo złe prognostyki i miały w polskiej ikonografii politycznej długą tradycję ${ }^{12}$.

Należy podkreślić, że zarówno w Scenie tragiczno-lirycznej, w Łysej radzie kolbuszowskiej, jak i w Prawdzie obiaśnionej Hadziewicza to właśnie August III ostatecznie zaprowadza w Rzeczypospolitej ład prawny. Istotnie to ten właśnie monarcha powołał do życia specjalną komisję, zwaną - od miejsca urzędowania - dubieńską, która miała ocenić stan prawny i faktyczny związany z podziałem ordynacji ostrogskiej.

$\mathrm{Tu}$ jednak należy uczynić pewną istotną dygresję. Nie tylko sam podział ordynacji ostrogskiej budził uzasadnione zastrzeżenia co do jej legalności. Takie same wątpliwości rodził zajazd, w lutym 1754 r., przez ludzi Jana Klemensa Branickiego Dubna. Zaznaczmy, że wojewoda smoleński Paweł Sapieha w miesiąc po owym zajeździe pisał do strażnika koronnego Stanisława Lubomirskiego, relacjonując swoją rozmowę ze stronnikiem hetmana Branickiego, Antonim Potockim, co następuje: „Wojewoda bełski tu dziś stanął, był u mnie chorego w dyskursie o tej ordynacji bardzo ozięble ze mną

\footnotetext{
${ }^{10}$ Łacińskie motto brzmi: „Illudit, sed ruere nescit inconcussa Virtus”, inskrypcja natomiast: „Sorte tamen in aequali”.

${ }^{11}$ Do tego tekst: „1753 die 19 XI ins. POTITUR NON PATITUR” oraz „Ziemia cmi miesiąc w pełni: Ostrogski nie gaśnie, W pełni szczęścia honoru: tak prawo chie (chce) właśnie”.

${ }^{12}$ Por. na przykład Chrościcki passim.
} 
mówił, ale widzę że po części wstydzą się co zrobili" ${ }^{13}$. Współcześni zdawali sobie zresztą sprawę z ogromnego zakresu kompetencji samej dubieńskiej komisji. Prymas Adam Ignacy Komorowski pisał do Stanisława Lubomirskiego:

List ostatni Wszey Mci z communikowanym Diariuszem Dubieńskiey kommisyi z należytym odbieram respektem $\mathrm{w}$ ktorym doczytuię się roznych contram legem expressam postępków (...). Za tym ten nowy w Dubnie Trybunał evertus statum nie ma sobie praesumere, tego czego sobie nie pozwalają Trybunały Główne Koronne ${ }^{14}$.

Nic więc dziwnego, że członkowie komisji dubieńskiej robili wszystko, co było możliwe, aby akcentować legalność swoich działań. Zarówno lektura komisyjnego diariusza, jak i relacji prasowych wskazuje, że w działalności komisji przyjęto ceremoniał wzorowany na ceremoniale Trybunału Koronnego. To oczywiście nie przypadek, bo ta instytucja była silnie zakorzeniona zarówno w ówczesnym polskim systemie prawnym, jak i szeroko rozumianej obyczajowości. Badacze ceremoniału politycznego nowożytnej Europy niejednokrotnie zwracali uwagę, że cykliczność form ceremonialnych uosabiała porządek władzy i jej stabilność, będący przeciwwagą dla chaosu (bezrządu) $)^{15}$. Jako że władza miała charakter sakralny, częste było przyjmowanie form liturgicznych $\mathrm{w}$ ceremoniale politycznym. Zostało to swego czasu przeanalizowane na przykładzie ceremoniału Trybunału Koronnego (Gombin, Trybunat Koronny passim), odnieść można to również do komisji ostrogskiej.

Prace komisji bardzo syntetycznie analizował już Henryk Palkij (313314). Działała ona od listopada 1754 do lutego 1756 r. pod przewodnictwem biskupa krakowskiego Andrzeja Załuskiego. Oficjalne prace rozpoczęła 26 listopada na dubieńskim zamku w obecności licznie zgromadzonej szlachty. Dzień wcześniej przybyli członkowie komisji, z hetmanem wielkim litewskim Michałem Radziwiłłem na czele, zostali uroczyście przywitani przez władze miasta. Na spotkanie komisarzy wyruszył liczący dwudziestu czterech żołnierzy oddział z Antonim Rostkowskim na czele. Po uroczystym powitaniu nastąpiła msza $\mathrm{w}$ kościele parafialnym ${ }^{16}$. Przybyli na obrady

${ }^{13}$ AGAD, Archiwum Potockich z Łańcuta, sygn. 1833. List z 22 III 1754 r.

${ }^{14}$ AGAD, Archiwum Potockich z Łańcuta, sygn. 1825. List Prymasa Adama Ignacego Komorowskiego do Stanisława Lubomirskiego z 5 I 1755 r.

${ }^{15}$ Por. na przykład: Muir, Civic ritual passim; Muir, Ritual in Early Modern Europe passim; Gombin, Trybunat Koronny passim.

${ }^{16}$ Biblioteka Polskiej Akademii Umiejętności w Krakowie, sygn. 1118, Journal de la Comission de Dubno k.1. 
biskup Andrzej Załuski oraz hetman Jan Klemens Branicki byli witani kanonadą z dział (Kuryer Polski, 1754, nr 72). Podobnie jak w przypadku Trybunału Koronnego, świętowano rocznicę koronacji Augusta III.

W piątek przeszły [17 stycznia - K.G.] iako in die anniwersarza Koronacyi Nayiaśnieyszego Króla Jmci Szczęśliwie Panuiącego, znaiduiący się Jchmć, udali się z Zamku do Kościoła Farnego, gdzie celebrował Mszę Świetą Xiążę Jmć Biskup Krakowski, przy odgłosie trąb kotłów y muzyki. Po Mszy śpiewano Te Deum laudamus przy rzęsistym ognia $\mathrm{z}$ armat, po Bateriach Fortecy tuteyszey dawaniu (...) Wieczorem nastąpiła illuminacya y fajerwerk piękną intencyą. Daley kolacya, a po niey tańce w pozną noc z ukontentowaniem wszystkich przytomnych. (Kuryer Polski, 1754, nr 72)

W Kurierze Polskim poza relacjami z rutynowych, rzec można, czynności komisarzy (1754, nr 72) znalazły się liczne opisy uroczystości z ich udziałem. Świętowano także imieniny żony Branickiego oraz pobyt w Dubnie posła tureckiego Alego Agi (1755, nr 123; 1755, nr 127. Suplement). Uroczystą oprawę miała ceremonia poświęcenia chorągwi batalionu dubieńskiego (Kuryer Polski, 1755, nr 133). Członkowie komisji z Branickim na czele brali też udział, podobnie jak deputaci trybunalscy, w uroczystościach rodzinnych okolicznej szlachty, takich jak chrzciny ${ }^{17}$ czy wesela ${ }^{18}$.

„Nowy w Dubnie Trybunał”, jak określił komisję „ostrogską” prymas Adam Ignacy Komorowski, to wydarzenie istotnie szczególne i wzbudzające niemałe kontrowersje wśród współczesnych. Jego główni aktorzy dbali, aby z obrad wychodziło jednolite przesłanie zgodnej pracy dla odtworzenia ładu prawnego w Rzeczypospolitej, co doskonale korespondowało z treściami płynącymi z innych form ówczesnego przekazu politycznego: grafiki i satyry.

\section{BIBLIOGRAFIA}

\section{ŹRÓDŁA NIEPUBLIKOWANE}

Archiwum Główne Akt Dawnych [AGAD]:

Archiwum Potockich z Łańcuta, sygn. 1833. List Pawła Sapiehy do Stanisława Lubomirskiego z 22 III 1754 r.

${ }^{17}$ Kuryer Polski, 1756, nr 134: „,z Dubna 31 Januarii ,[...] były solenne Chrzciny w Kaplicy Zamkowey Syna Jchmciow Popielów starostów ceceniowskich; ktorego do chrztu trzymali”). „In gratiam tych chrzcin nazaiutrz była w Zamku Gala przy liczney kompanii dystyngowanych Gości bawiących się do drugiey godziny w noc asamblami”.

${ }^{18}$ Kuryer Polski, 1755, nr 83. Suplement: „W Brodach 2 lutego ślub Panny Wojewodzianki kijowskiej starszej z p. Moszyńskim Stolnikiem Koronnym”. 
Archiwum Potockich z Łańcuta, sygn. 1825. List Prymasa Adama Ignacego Komorowskiego do Stanisława Lubomirskiego z 5 I 1755 r.

Zbiór Anny z Potockich Ksawerowej Branickiej, sygn. 1813. Ordynacja ostrogska. Prawdzic do niewiadomego.

Zbiór Anny z Potockich Ksawerowej Branickiej, sygn. 469. Rękopisy dotyczące ordynacji ostrogskiej.

Zbiór Branickich z Suchej, sygn. 131. Manuscripta anni 1754.

Biblioteka Jagiellońska, rkps 1808 IV. Scena tragiczno-komiczna publicznym światu polskiego theatrum pokazana wyrok niewinnej śmierci i cudownego po tym uwolnienie ordynacyi ostrogskiej prezentująca Ojczysta Muza przez jednego ze spektatorów opisana.

Biblioteka Polskiej Akademii Umiejętności w Krakowie, sygn. 1118. Journal de la Comission de Dubno.

\section{ŹrÓDŁA PUBLIKOWANE}

Akta publiczne do interessu ordynacji ostrogskiej należące [b.d.m.w.], ok. 1754.

Hadziewicz, Piotr. Prawda obiaśniona, pozory przyćmione, ordinacyia obroniona to iest odpowiedź na ksiąszkę [sic!] Uwagi w sprawie ordynacyi ostrogskiey oraz Wolność oswobodzona z niewoli swawolney ubezpieczone prawa y seymy oswobodzona oyczyzna, Wrocław, 1756.

Kuryer Polski 1754-1756.

Łubieński, Maciej. Kazanie na seymie ordynatyinym warszawskim Roku Pańskiego 1754 przez Macieja Józefa z Łubny Łubieńskiego Archidiakona Katedralnego Krakowskiego, proboszcza Kollegiaty S. Michała na Zamku w Krakowie miane Y do druku za pozwoleniem Starszych Roku tegoż podane. A po tym dla niedostatku Exemplarzow z poprawa errorów druku, ktore się $w$ tamtych znaydowaty, w Roku następuiacym przedrukowane, w Krakowie w Drukarni J.O Jego MCI Biskupa Krakowskiego.

\section{OPRACOWANIA}

Buchwald-Pelcowa, Paulina. Satyra czasów saskich. Ossolineum, 1969.

Chrościcki, Juliusz A. „Gigantomachia, komety i ulotki. Studia nad ikonografią oblężenia Jasnej Góry w roku 1655”. Studia Claromontana, t. 7, 1987, ss. 121-133.

Gombin. Krzysztof. Trybunat Koronny. Ceremoniat i sztuka. Wydawnictwo KUL, 2013.

Gombin, Krzysztof. „O reminiscencjach konfliktu o ordynację ostrogską w sztuce kręgu Jana Klemensa Branickiego". Roczniki Humanistyczne, t. 68, z. 4, 2020. ss. 191-203.

Górska, Magdalena. Polonia - Respublica - Patria. Personifikacje Polski w sztuce XVI-XVIII wieku. Wydawnictwo Uniwersytetu Wrocławskiego, 2005.

Konopczyński, Władysław. „Ostrogska ordynacja”. Wielka Encyklopedia Powszechna Ilustrowana, seria II, t. V-VI, Nakład i druk S. Sikorski, 1908, ss. 793-797.

Konopczyński, Władysław. Polska $w$ dobie wojny siedmioletniej, cz. I, W.L Anczyc, 1909.

Muir, Edward. Civic ritual in Renaissance Venice. Princeton University Press, 1986.

Muir, Edward. Ritual in Early Modern Europe. Cambridge University Press 1997.

Palkij, Henryk. „Ceremoniał podczas różnego rodzaju komisji w czasach saskich”. Theatrum ceremoniale na dworze królów i książą polskich. Materiały konferencji naukowej zorga- 
nizowanej przez Zamek Królewski na Wawelu i Instytut Historii Uniwersytetu Jagiellońskiego w dniach 23-25 marca 1998, red. Mariusz Markiewicz i Ryszard Skowron, Zamek Królewski na Wawelu, 1999, ss. 313-314.

Szwaciński, Tomasz. „Rosja a Piotr i Jan Sapiehowie w dobie kryzysu ostrogskiego”. Kwartalnik Historyczny, t. 119, nr 1, 2012, ss. 31-65.

Więcek, Adam. Strachowscy. Z dziejów ilustratorstwa śląskiego XVIII wieku. Ossolineum,1960.

Witwińska, Magdalena. „Rokokowa polichromia Walentego Żebrowskiego w kościele św. Anny”. Kronika Warszawy, nr 1-2, 1972, ss. 53-66.

\section{O OBRAZOWANIU IDEI SPRAWIEDLIWOŚCI \\ W RZECZYPOSPOLITEJ POŁOWY XVIII WIEKU - WOKÓŁ KONFLIKTU O ORDYNACJĘ OSTROGSKĄ}

\section{Streszczenie}

Celem artykułu jest ukazanie wzajemnych relacji sztuk plastycznych, ceremoniału oraz publicystyki w propagandzie politycznej Rzeczypospolitej czasów Augusta III, na kluczowym dla ówczesnego życia publicznego przykładzie - sporze o ordynację ostrogską. W satyrycznej Scenie tragiczno-komicznej zawarcie tzw. transakcji kolbuszowskiej, sankcjonującej podział ordynacji, przedstawione zostało jako akt bezprawia - parodia sądów Rzeczypospolitej. Z przekazu zawartego w rycinach rozprawy Piotra Hadziewicza, Prawda obiaśniona... wynikało, że jedność i ład w państwie muszą być oparte na przestrzeganiu praw, czego gwarantem jest król. August III utworzył obradującą w Dubnie komisję, mającą ocenić zasadność podziału ordynacji. Jej członkowie, akcentując legalność działań, przyjęli porządek obrad wzorowany na ceremoniale Trybunału Koronnego, instytucji silnie zakorzenionej w ówczesnym polskim systemie prawnym. Główni aktorzy „Nowego w Dubnie Trybunału”, jak określił komisję prymas Adam Komorowski, dbali o jednolity dla opinii publicznej przekaz: zgodnej pracy dla odtworzenia ładu prawnego w Rzeczypospolitej, co doskonale korespondowało z treściami ówczesnej grafiki i satyry.

Słowa kluczowe: ceremoniał polityczny; archeologia prawna; ordynacja ostrogska; komisja dubieńska; satyra; grafika polska XVIII wieku.

\section{DEPICTIONS OF THE IDEA OF JUSTICE \\ IN MID-18TH CENTURY POLAND: ON THE CONFLICT OVER THE OSTROGSKI ESTATE}

\section{Su m mary}

This article aims to show the interrelation between the visual arts, ceremonials and journalistic opinion pieces in the political propaganda of the Polish-Lithuanian Republic during the reign of King Augustus III, using an example which was of vital importance for the public life of that time - the dispute over the entail of the Ostrogski estate. In the satirical Tragic-Comic Scene, the conclusion of the so-called Kolbuszowa Transaction, sanctioning the division of the estate's entail, was presented as a parody of the courts then operating in the Republic. The illustrations for Piotr Hadziewicz's dissertation Prawda obiaśniona... conveyed the message that the unity and order of the state must be based upon the observance of its laws, with the King being 
the guarantor of the legal order. The king established a special commission, known as the Dubno Commission, which was to assess the legal and factual status related to the division of the Ostrogski estate. The committee members strongly emphasised the legality of their actions. They adopted a ceremonial which was modelled on the ceremonies of the Crown Tribunal, an institution deeply rooted in the Polish legal system of that time. The main actors of the "new Tribunal in Dubno", as Primate Adam Ignacy Komorowski described the Commission, made sure that a uniform message was sent out to the public: that of the harmonious work by the Commission to restore the legal order in the Republic. This message perfectly corresponded with the content of the illustrations and satire of that period.

Keywords: political ceremonial; legal archaeology; the Ostrogski estate; the Dubno Commission; satire; Polish illustrations of the 18th century. 


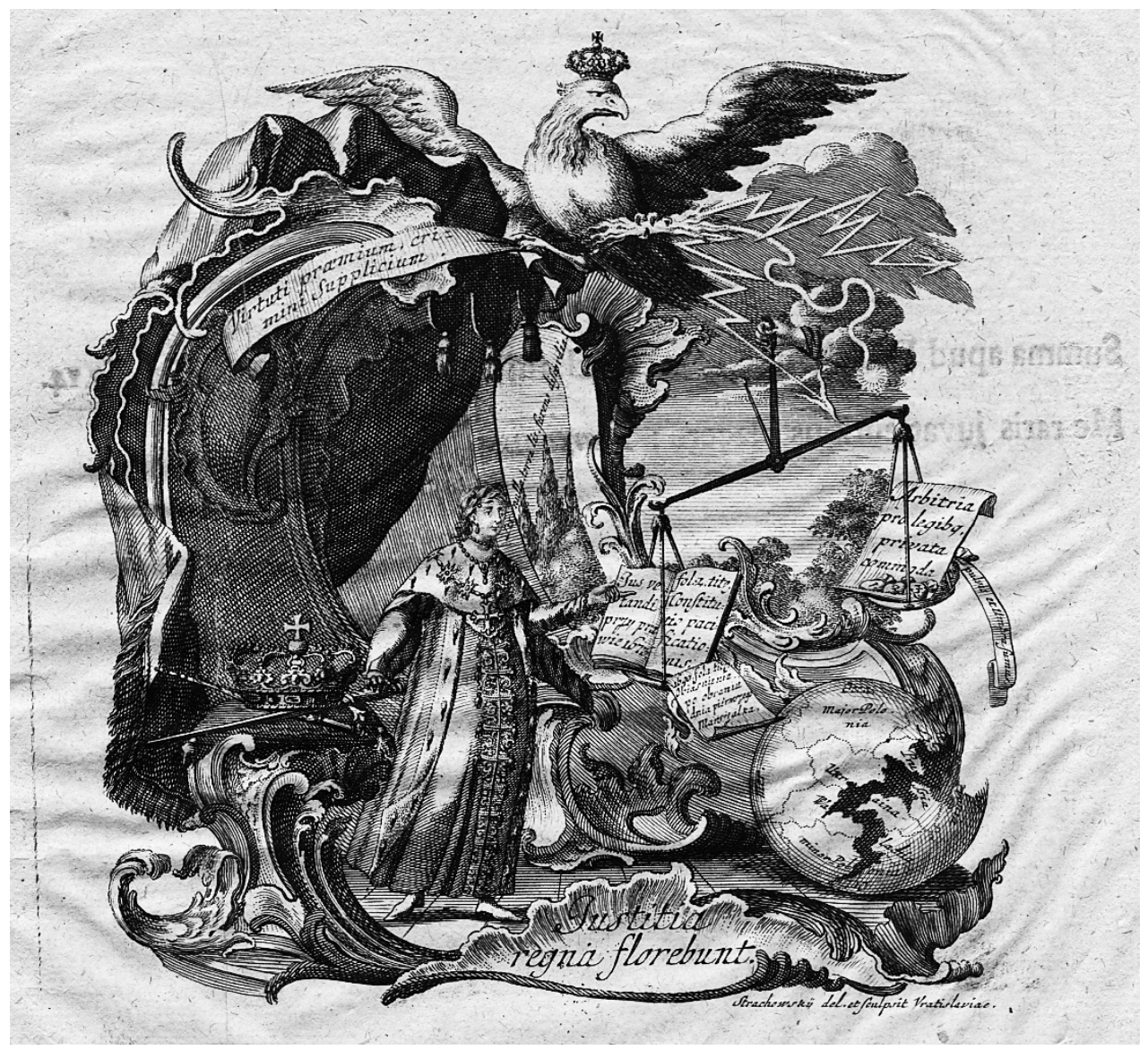

1. Bartłomiej Strachowski, Ilustracja do dzieła Piotra Hadziewicza Prawda obiaśniona, Wrocław, 1754, strona tytułowa 


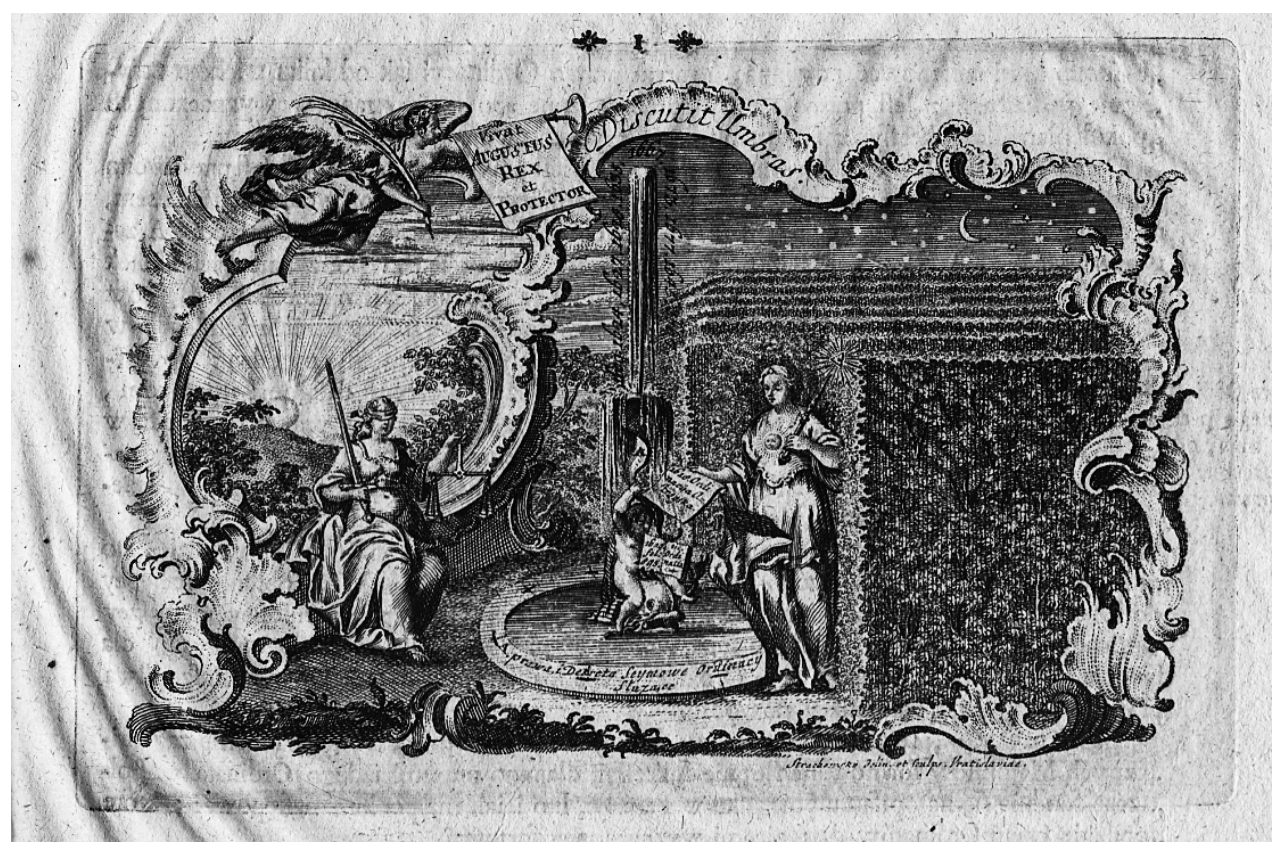

2. Bartłomiej Strachowski, Ilustracja do dzieła Piotra Hadziewicza Prawda obiaśniona, Wrocław, 1754, strona 2

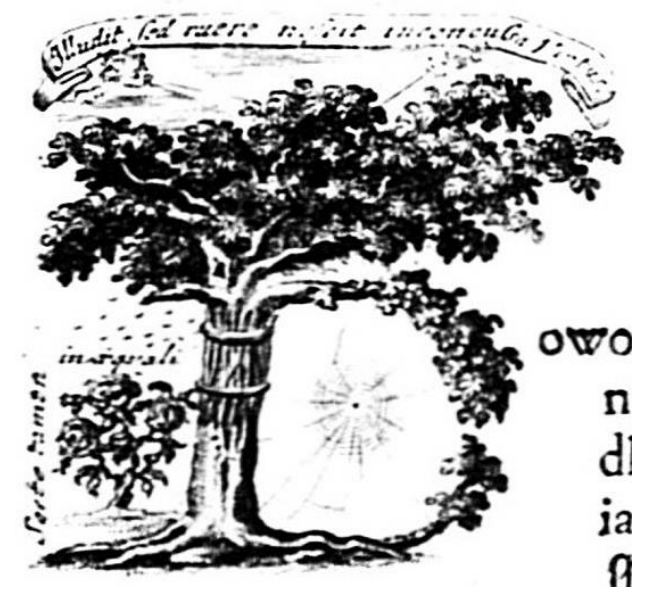

3. Bartłomiej Strachowski, Ilustracja do dzieła Piotra Hadziewicza Prawda obiaśniona, Wrocław, 1754, inicjał na stronie 2 


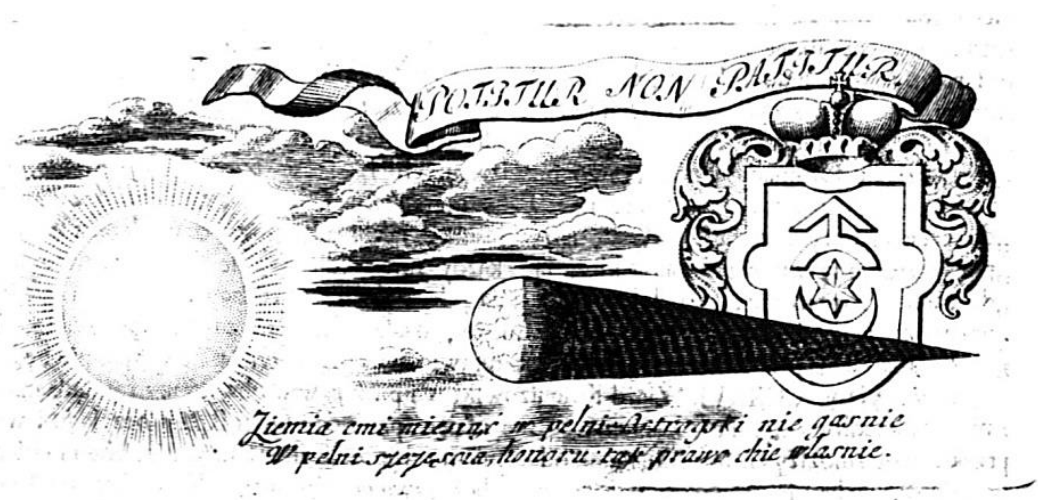

4. Bartłomiej Strachowski, Ilustracja do dzieła Piotra Hadziewicza Prawda obiaśniona, Wrocław, 1754, strona 76 